\title{
Common best proximity points for proximity commuting mapping with Geraghty's functions
}

\section{POOM KUMAM and CHIRASAK MONGKOLKEHA}

\begin{abstract}
.
In this paper, we prove new common best proximity point theorems for proximity commuting mapping by using concept of Geraghty's theorem in complete metric spaces. Our results improve and extend recent result of Sadiq Basha [Basha, S. S., Common best proximity points: global minimization of multi-objective functions, J. Glob Optim, 54 (2012), No. 2, 367-373] and some results in the literature.
\end{abstract}

Acknowledgements. This work was supported by the Higher Education Research Promotion and National Research University Project of Thailand, Office of the Higher Education Commission (NRU2558). Moreover, Mr. Chirasak Mongkolkeha was supported from Kasetsart University Research and Development Institute (KURDI).

\section{REFERENCES}

[1] Al-Thagafi, M. A. and Shahzad, N., Convergence and existence results for best proximity points, Nonlinear Anal., 70 (2009), No. 10, 3665-3671

[2] Bari, C. D., Suzuki, T. and Vetro, C., Best proximity points for cyclic Meir-Keeler contractions, Nonlinear Anal., 69 (2008), No. 11, 3790-3794

[3] Basha, S. S and Veeramani, P., Best proximity pair theorems for multifunctions with open fibres, J. Approx. Theory, 103 (2000), 119-129

[4] Basha, S. S, Common best proximity points: global minimization of multi-objective functions, J. Glob Optim., $5 \mathbf{4}$ (2012), No. 2, 367-373

[5] Boyd, D. W. and Wong, J. S. W., On nonlinear contractions, Proc. Amer. Math. Soc., 20 (1969), 458-464

[6] Fan, K., Extensions of two fixed point theorems of F. E. Browder, Math. Z., 112 (1969), 234-240

[7] Geraghty, M., On contractive mappings, Proc. Amer. Math. Soc., 40 (1973), 604-608

[8] Jungck, G., Commuting mappings and fixed points, Am. Math. Mon., 83 (1976), 261-263

[9] Mongkolkeha, C. and Kumam, P., Some common best proximity points for proximity commuting mappings, Optim Lett., 7 (2013), 1825-1836

[10] Prolla, J. B., Fixed point theorems for set valued mappings and existence of best approximations, Numer. Funct. Anal. Optim., 5 (1982-1983), 449-455

[11] Reich, S., Approximate selections, best approximations, fixed points and invariant sets, J. Math. Anal. Appl., 62 (1978), 104-113

[12] Sehgal, V. M. and Singh, S. P., A generalization to multifunctions of Fan's best approximation theorem, Proc. Amer. Math. Soc., 102 (1988), 534-537

[13] Sehgal, V. M. and Singh, S. P., A theorem on best approximations, Numer. Funct. Anal. Optim., 10 (1989), $181-184$

[14] Zhang, X., Common xed point theorems for some new generalized contractive type mappings, J. Math. Anal. Appl., 333 (2007), 780-786

Received: 30.08.2014; In revised form: 02.03.2015; Accepted: 10.03.2015

2010 Mathematics Subject Classification. 47H10, 47H09.

Key words and phrases. Best proximity point, common best proximity point, Geraghty's condition, commute proximity mapping, Generalized contraction.

Corresponding author: Chirasak Mongkolkeha; faascsm@ku.ac.th 
DEPARTMENT OF MATHEMATICS

FACULTY OF APPLIED SCIENCE

King MONGKUT'S UniVERSITY OF TECHNOlogy ThONBURI (KMUTT)

126 Pracha Uthit RoAD, BANG MOD, Thrung KRU, BANGKOK 10140, Thailand

E-mail address: poom. kum@kmutt.ac.th

DePARTMENT OF MATHEMATICS STATISTICS AND COMPUTERS

FACULTY OF LIBERAL ARTS AND SCIENCE, KASETSART UNIVERSITY

KAMPHAENG-SAEN CAMPUS, NAKHONPATHOM 73140, THAILAND

E-mail address: faascsmeku.ac.th 